\title{
Effect of Environmental Heavy Metal Pollution on Metabolic Profile of Buffaloes in Ludhiana
}

\author{
Pranesh V. Yeotikar, Shashi Nayyar, Chanchal Singh,
} C.S. Mukhopadhyay, Rajesh Jindal, Sushma Chhabra

10.18805/ajdfr.DR-1738

\begin{abstract}
Background: The industrial hub of Punjab, Ludhiana is polluted with heavy metals. The dairy animals experience stress due to pollution of heavy metals as well as the hot summer season. The stressors lead to disturbance in metabolic profile and affect milk production. The present study aimed at evaluation of detrimental effect of environmental heavy metal pollution on the metabolic profile of buffaloes during summer and winter seasons in Ludhiana district of Punjab, India. A total of 100 buffaloes were randomly selected from heavy metal exposed $(n=60)$ and control area $(n=40)$ during summer and winter seasons.

Methods: The location of the experimental area surveyed on the basis of levels of heavy metals. The dairy farms are located in and around Ludhiana, Punjab were identified with levels of heavy metal above the permissible limits (FSSAl, 2010) viz. Chromium-0.05 $\mu \mathrm{g}$ $/ \mathrm{ml}$; Nickel-0.02 $\mu \mathrm{g} / \mathrm{ml}$; Arsenic- $0.05 \mu \mathrm{g} / \mathrm{ml}$ and Lead $-0.05 \mu \mathrm{g} / \mathrm{ml}$. The plasma samples were analyzed for metabolic profile. The water levels of heavy metals were below the permissible limits; therefore, it was taken as uncontaminated or control area.

Result: Buffaloes of heavy metal exposed areas exhibited significantly $(P<0.05)$ higher levels of glucose, total cholesterol, triglycerides, BUN, creatinine, AST, ALT, GGT, ALP and CK levels as compared to control area. A significant $(\mathrm{P}<0.05)$ decrease was observed in plasma total protein, albumin, A:G ratio, BUN: creatinine ratio in the buffaloes of exposed area as compared to the control area. However, significantly $(\mathrm{P}<0.05)$ higher levels of plasma glucose, BUN, creatinine, AST, ALT, GGT, ALP and CK levels were observed during summer as compared to winter season in both exposed and control areas. Significantly $(P<0.05)$ decreased levels of plasma total cholesterol, triglycerides, total protein, albumin and BUN: Creatinine ratio were observed in the buffaloes during summer as compared to winter in both exposed and control areas. The $\mathrm{Cr}, \mathrm{Ni}, \mathrm{As}$ and $\mathrm{Pb}$ levels showed highly significant $(\mathrm{P}<0.01)$ positive correlation with plasma levels of glucose, total cholesterol, creatinine, ALT, AST, CK and GGT. Highly significant positive relationship $(P<0.01)$ was observed among plasma levels of glucose, total cholesterol, creatinine, BUN, ALT, AST, ALP, CK and GGT whereas, plasma BUN had highly significant $(P<0.01)$ negative correlation with plasma total protein and $A: G$ ratio considering both the areas together. Plasma levels of total protein showed significant $(P<0.01)$ negative correlation with all other metabolic profile constituents of both control and heavy metal exposed areas. Thus it may be concluded that the metabolic disturbance in heavy metal exposed buffaloes may have been mediated by heavy metal pollution.
\end{abstract}

Key words: Arsenic, Bubalus bubalis, Chromium, Enzymes, Lead, Metabolic profile, Nickel, Season.

\section{INTRODUCTION}

Industrial effluents instigating heavy metals pollution creates their potential accumulation in the biological eco system which may cost a serious environmental and health issues lasting for decades (Chopra et al., 2009 and Christiana and Samuel, 2013). Metals in higher concentrations pollute surface and groundwater resources and acts as toxicants for humans and animals. Generally, water level of heavy metals are increased in summer and decreased in winter (Ozan, 2015). Toxicity of environmental contaminants like arsenic and chromium and may affect global health. Arsenic and chromium are widely distributed in nature (Vimercati et al., 2017). The international Agency for Research on cancer, classified the Arsenic, Cadmium, Chromium and Nickel are toxic heavy metals are known to cause cancers. The exposure of heavy metals leads to metabolic disturbances via disruption of enzymatic activities (Banfalvi, 2011). Arsenic toxicity can disrupt hepatic function due to cross linking of enzymes (Patlolla et al., 2012). Even at low levels, heavy metals can upset the normal body function, by playing as
Department of Veterinary Physiology and Biochemistry, College of Veterinary Science, Guru Angad Dev Veterinary and Animal Sciences University, Ludhiana-141 004, Punjab, India.

Corresponding Author: Shashi Nayyar, Department of Veterinary Physiology and Biochemistry, College of Veterinary Science, Guru Angad Dev Veterinary and Animal Sciences University, Ludhiana141 004, Punjab, India. Email: shashi.0741@ gmail.com.

How to cite this article: Yeotikar, P.V., Nayyar, S., Singh, C., Mukhopadhyay, C.S., Jindal, R., Chhabra, S. (2021). Effect of Environmental Heavy Metal Pollution on Metabolic Profile of Buffaloes in Ludhiana. Asian Journal of Dairy and Food Research. DOI: 10.18805/ajdfr.DR-1738.

Submitted: 31-05-2021 Accepted: 09-09-2021

Online: $24-09-2021$

endocrine disruptors, production of reactive oxygen metabolites, hindering of essential functional groups or displacing the essential metal ions from biomolecules, leading to loss or inhibition of various enzyme activities and modification of metabolism (Lavicoli et al., 2009), resulting 
in physiological or biochemical alterations in the animal. The higher concentrations of hexavalent $\mathrm{Cr}$ in blood may cause blood cell damage leads to functional damage of Liver and Kidney and mainly induces apoptosis (Dartsch et al., 1998). Nickel exposure through contaminated water leads to dermatitis and allergy of skin and oral epithelium damage (Jacob et al., 2015). The heavy metal exposure may also induce damage to blood composition, kidneys, lungs, liver and reduction in energy levels (Hajeb et al., 2014). The heavy metals affect all over the body including may leads to disruption the hematology, cardiovascular, renal and neural functions (Assi et al., 2016). The metals by inhibiting or interfering with enzyme function may affect gly-colysis, krebs cycle, nucleic acid metabolism, protein metabolism as well as the pentose phosphate pathway (Strydom et al., 2006). The heavy metals overload in tissues and exert their toxic effects on living organismmay also affect oxidative metabolism such as glycolysis, protein and lipid profile which later cause the oxidative stress (Javed et al., 2017). Keeping this in view, the present study is therefore focusedon the effect of heavy metals on the metabolic profile of buffaloes in heavy metal exposed areas of Ludhiana district of Punjab, India during summer and winter seasons.

\section{MATERIALS AND METHODS} Ethical approval

Experimental procedures using buffaloes in this study have been conducted after approval from the Institutional Animal Ethical Committee (IAEC) of the Guru Angad Dev Veterinary and Animal Sciences University, Ludhiana, Punjab, India. All the research investigations withbuffalo were carried out according to the IAEC guidelines (Proceedings of XXXVII meeting vide memo No. IAEC/2016/643-675 dated 19.10.2016, Proposal no. GADVASU/2016/IAEC/37/20).

\section{Selection of area}

The basis of selection of exposed and the control area of the present study was the levels of $\mathrm{Cr}, \mathrm{Ni}, \mathrm{As}$ and $\mathrm{Pb}$ in the drinking water. The area having the drinking water levels of $\mathrm{Cr}, \mathrm{Ni}, \mathrm{As}$ and $\mathrm{Pb}$ below the permissible limits was considered as control area whereas, the area having the drinking water levels of $\mathrm{Cr}, \mathrm{Ni}, \mathrm{As}$ and $\mathrm{Pb}$ above the permissible limits was considered as exposed area. The permissible limit of drinking water for Chromium- $0.05 \mu \mathrm{g} / \mathrm{ml}$, Nickel-0.02 $\mu \mathrm{g} / \mathrm{ml}$, Arsenic$0.05 \mu \mathrm{g} / \mathrm{ml}$ and Lead-0.05 $\mu \mathrm{g} / \mathrm{ml}$ (FSSAl, 2010) (Yeotikar et al., 2018).

\section{Experimental animals}

\section{Group I / control area}

A total of 40 Murrah lactating buffaloes selected on the basis of residing in the area where the heavy metals in the drinking water were below the permissible limits (Chromium-0.05 $\mu \mathrm{g} / \mathrm{ml}$, Nickel-0.02 $\mu \mathrm{g} / \mathrm{ml}$, Arsenic $-0.05 \mu \mathrm{g} / \mathrm{ml}$ and Lead$0.05 \mu \mathrm{g} / \mathrm{ml}$ ) during both summer and the winter seasons were used in the experiment.

\section{Group II / exposed area}

A total of 60 Murrah lactating buffaloes selected on the basis of residing in the area where the heavy metals in the drinking water above the permissible limits (Chromium- $0.05 \mu \mathrm{g} / \mathrm{ml}$, Nickel-0.02 $\mu \mathrm{g} / \mathrm{ml}$, Arsenic $-0.05 \mu \mathrm{g} / \mathrm{ml}$ and Lead $-0.05 \mu \mathrm{g} / \mathrm{ml}$ ) during both summer and the winter seasons were used in the experiment.

All the experiments of the study were carried out by using lactating Murrah buffaloes (age 3-9 years). They were maintained in organized dairy farms by their owners in field conditions and provided with standard diet and ad libitum water.

\section{Temperature humidity index}

Temperature and relative humidity were recorded inside the shed with the help of thermo hygrometer. Temperature humidity index (THI) of the animal shed was calculated using the formula:

$$
\mathrm{THI}=(0.81 \times \mathrm{Ta})+\{(\mathrm{RH} \div 100) \times(\mathrm{Ta}-14.4)\}+46.6
$$

(Where, $\mathrm{Ta}=$ Average ambient temperature in ${ }^{\circ} \mathrm{C}$ and $\mathrm{RH}=$ Average relative humidity) (Lakhani et al., 2016).

\section{Collection of samples}

\section{Drinking water samples}

Drinking water samples were collected in duplicate in acidwashed polyethylene bottles. A total of 100 water samples were collected once in a season from tube wells of different sites of the study area of Ludhiana district. The water samples were collected in the exposed area $(n=60)$ during summer and winter season respectively. Whereas in the control area $(n=40)$ during summer and winter seasons respectively.

\section{Blood samples}

The blood samples $(5 \mathrm{ml})$ were collected in heparinized vials by jugular venipuncture from 100 buffaloes maintained at the dairy farms located in heavy metal exposed $(n=60)$ and control $(n=40)$ areas of Ludhiana district Punjab during summer (June - August 2017, mean THI=82.88) and winter (November - December 2017, mean THI= 64.58) seasons.

\section{Estimation of heavy metals in drinking water and blood samples}

Determinations of heavy metals were carried out using Perkin-Elmer Optima 2100 DV model ICP-OES equipped with an AS-93 autosampler which is one of the most powerful and popular elemental analysis techniques. All samples and blank solutions are measured in duplicate. Inductively coupled plasma-optical emission spectrometry (ICP-OES) (PERKINS ELMER OPTIMA 2100 DV MODEL) instrument was used for estimating the heavy metals and trace minerals with Optima's proven 32-bit Windows ${ }^{\circledR}$ software, $\mathrm{W}$ inLab32 ${ }^{\mathrm{TM}}$. The heavy metals $(\mathrm{Cr}, \mathrm{Ni}, \mathrm{As}$ and $\mathrm{Pb})$ were analyzed in digested and extracted samples. The working standards were analyzed at the beginning and end of a run and intermittently during longer runs. According to the 
absorbance, the concentration was measured directly, when the sample was well within the linear working range of the standard curve. All analyses were performed in duplicate. Analytical blanks were run along with each batch of digestion set (Dhanalakshmi and Gawdaman, 2012).

\section{Acid digestion of water and blood samples Digestion of water samples}

Drinking water samples were digested by following the method of McGraths and Cunliffe (1995) with slight modifications. The water samples $(10 \mathrm{ml})$ were added 10 $\mathrm{ml}$ of diacid (70 $\mathrm{ml}$ of Nitric acid $+30 \mathrm{ml}$ of Perchloric acid) and left overnight. This mixture was digested on the hot plate at $250^{\circ} \mathrm{C}$ until a colorless solution 1-3 ml volume appeared. The digested samples were filtered using Whatman filter paper no. 42 and made up the volume up to $10 \mathrm{ml}$ with double glass distilled water.

\section{Acid digestion of blood samples}

All glass wares were first cleaned with $10 \% \mathrm{HNO}_{3}$ solution and then further washed with the distilled water and then sterilized in the hot air oven at $160^{\circ} \mathrm{C}$ for 60 minutes. The whole blood samples $(1 \mathrm{ml})$ were added $15 \mathrm{ml}$ of a tri-acid mixture (10:4:1 $\mathrm{HNO}_{3}, \mathrm{H}_{2} \mathrm{SO}_{4}$ and $\left.\mathrm{HClO}_{4}\right)$ and left overnight. This mixture was digested on a hot plate at $250^{\circ} \mathrm{C}$ until a colorless solution 1-2 $\mathrm{ml}$ volume appeared. The digested samples were filtered using Whatman No. 42 filter paper and the volume of filtrate was made up to $10 \mathrm{ml}$ with double glass distilled water (Allen et al. 1986).

\section{Estimation of metabolic parameters}

Plasma levels of glucose, total cholesterol, triglycerides, total protein, albumin, blood urea nitrogen, creatinine and activities of ALT, AST, GGT, ALP and CK which were determined by Autopak kits (BPC Biopac, SRL, Rome, Italy) on the fully automatic biochemical analyzer (Global 240 BPC Biosed). All determinations were performed in duplicate. Blood urea nitrogen (BUN) concentration in plasma was calculated from plasma urea concentration after dividing by 2.14. A:G ratio, BUN: Creatinine ratio and AST: ALT ratio was also calculated.

\section{Statistical methods}

The experimental data were subjected to two way analysis of variance with interactionusing SYSTAT 13 software Inc., CA, USA, ver. 13.00.05. The differences between the mean values of the parameters belonging to the experimental groups reared during summer and winter seasons were analyzed for significant differences using Duncan's multiple range post hoc test.The normality of the data and autocorrelation between the groups were tested by Kolmogorov-Smirnov test (Lilliefors) and Durbin-Watson DStatistic, respectively. Pearsonian correlation among the metabolic profile parameters was determined.

\section{RESULTS AND DISCUSSION}

The mean values of glucose, BUN and creatinine were significantly $(P<0.05)$ higher in the exposed area as compared to control area during both summer and winter seasons (Table 1). The levels of total cholesterol, triglycerides, albumin and globulin were significantly $(P<0.05)$ higher in buffaloes of the exposed area during both the seasons. However, the levels of total cholesterol, triglycerides, albumin and globulin were significantly $(P<0.05)$ lower in buffaloes of the exposed area during the summer as compared to winter season. The levels of total protein, albumin and BUN: Creatinine ratio were significantly $(P<0.05)$ lower in buffaloes of the exposed area as compare to control area and during the summer as compared to winter

Table 1: Metabolic profile (mean \pm S.E.) of buffaloes of control and exposedareas during different seasons.

\begin{tabular}{|c|c|c|c|c|}
\hline \multirow{2}{*}{$\begin{array}{l}\text { Blood biochemical } \\
\text { constituents }\end{array}$} & \multicolumn{2}{|c|}{ Control group $(n=40)$} & \multicolumn{2}{|c|}{ Exposed group $(n=60)$} \\
\hline & Winter & Summer & Winter & Summer \\
\hline Glucose (mg/dL) & $54.24^{\mathrm{a}} \pm 1.46$ & $72.64^{b} \pm 1.95$ & $84.93^{c} \pm 0.86$ & $96.41^{d} \pm 0.69$ \\
\hline Total cholesterol (mg/dL) & $103.04^{\mathrm{a}} \pm 0.67$ & $92.49^{b} \pm 1.59$ & $136.81^{\mathrm{c}} \pm 1.37$ & $123.87^{d} \pm 2.13$ \\
\hline Triglycerides (mg/dL) & $16.41^{\mathrm{a}} \pm 0.65$ & $13.66^{\mathrm{b}} \pm 0.43$ & $23.65^{a} \pm 0.78$ & $19.39^{c} \pm 1.44$ \\
\hline Total proteins (g/dL) & $7.58^{a} \pm 0.12$ & $5.57^{b} \pm 0.09$ & $5.74^{b} \pm 0.10$ & $5.07^{c} \pm 0.06$ \\
\hline Albumin $(\mathrm{g} / \mathrm{dL})$ & $3.44^{\mathrm{a}} \pm 0.07$ & $2.96^{\mathrm{b}} \pm 0.06$ & $1.63^{\mathrm{c}} \pm 0.03$ & $1.47^{b} \pm 0.06$ \\
\hline Globulin (g/dL) & $3.99^{\mathrm{a}} \pm 0.09$ & $2.61^{\mathrm{a}} \pm 0.11$ & $4.12^{\mathrm{b}} \pm 0.12$ & $3.59^{c} \pm 0.07$ \\
\hline A:G Ratio & $0.93^{a} \pm 0.02$ & $1.24^{b} \pm 0.07$ & $0.42^{c} \pm 0.02$ & $0.43^{b} \pm 0.03$ \\
\hline BUN (mg/dL) & $26.61^{\mathrm{a}} \pm 0.53$ & $31.08^{\mathrm{b}} \pm 0.47$ & $31.97^{c} \pm 0.34$ & $37.47^{d} \pm 0.37$ \\
\hline Creatinine (mg/dL) & $1.28^{a} \pm 0.01$ & $1.57^{b} \pm 0.04$ & $2.32^{c} \pm 0.01$ & $2.76^{d} \pm 0.02$ \\
\hline BUN: creatinine ratio & $20.76^{\mathrm{a}} \pm 0.43$ & $20.14^{b} \pm 0.43$ & $14.65^{\mathrm{a}} \pm 0.14$ & $13.64^{c} \pm 0.20$ \\
\hline AST (U/L) & $91.71^{\mathrm{a}} \pm 1.98$ & $108.21^{b} \pm 2.49$ & $129.15^{\mathrm{c}} \pm 2.70$ & $137.62^{\mathrm{d}} \pm 3.80$ \\
\hline ALT (U/L) & $29.84^{\mathrm{a}} \pm 0.89$ & $41.40^{\mathrm{b}} \pm 1.03$ & $45.32^{\mathrm{c}} \pm 1.11$ & $53.92^{\mathrm{d}} \pm 1.00$ \\
\hline GGT (U/L) & $20.72^{\mathrm{a}} \pm 1.80$ & $25.35^{\mathrm{b}} \pm 0.97$ & $36.98^{c} \pm 0.63$ & $43.07^{d} \pm 0.66$ \\
\hline ALP (U/L) & $150.50^{a} \pm 8.38$ & $205.19^{b} \pm 4.27$ & $247.79^{c} \pm 12.46$ & $281.68^{d} \pm 13.52$ \\
\hline CK (U/L) & $5.34^{\mathrm{a}} \pm 0.39$ & $6.95^{\mathrm{b}} \pm 0.44$ & $9.20^{\circ} \pm 0.20$ & $12.12^{\mathrm{d}} \pm 0.15$ \\
\hline
\end{tabular}

Superscripts $a, b, c$ and $d$ Means with no common superscripts are significantly different $(P<0.05)$ within each row between different seasons vis-à-vis groups. 
season in both the areas. The A: $G$ ratio values were significantly $(P<0.05)$ lower in exposed than control area; however, significantly $(P<0.05)$ higher during summer than winter season in both the areas.

\section{Pearson's correlation between heavy metals and blood biochemical constituents}

The $\mathrm{Cr}, \mathrm{Ni}, \mathrm{As}$ and $\mathrm{Pb}$ levels showed highly significant $(P<0.01)$ positive correlations with plasma levels of glucose, total cholesterol, creatinine and BUN whereas, they showed highly significant $(P<0.01)$ negative correlations with total protein, albumin and $A: G$ ratio considering both the areas together (Fig 1).

\section{Pearson's correlation among blood biochemical constituents}

Highly significant $(P<0.01)$ positive correlations was observed among plasma levels of glucose, total cholesterol, creatinine and BUN. However, plasma levels of total protein, albumin and $A: G$ ratio showed highly significant $(P<0.01)$ negative correlations with plasma glucose and total cholesterol. Total protein and A: $G$ ratio showed highly significant $(P<0.01)$ negative correlation with creatinine and BUN considering both the areas together (Fig 2).

\section{Pearson's correlation among plasma enzyme profile}

The ALT levels showed highly significant $(P<0.01)$ positive correlation with AST, ALP, CK and GGT. However, AST levels showed highly significant $(P<0.01)$ possitive correlation with $\mathrm{CK}$ and GGT considering both the areas together (Fig 3).

\section{Pearson's correlation between plasma enzymes profile} and blood biochemical constituents

Highly significant positive correlation $(P<0.01)$ was observed between plasma levels of ALT, AST, CK, GGT, glucose, total cholesterol, creatinine and BUN (Fig 3). However, plasma levels of total protein and albumin showed significant
$(P<0.01)$ negative correlation with all other constituents of metabolic profile studied considering both the areas together

The elevated levels of glucose in metal exposed buffaloes may be due to disturbed glucose metabolism. Arsenic and presence of heavy metals caused beta cell dysfunction may be arrested GLUT4 (Kazi et al., 2009 and Chen et al., 2009). The glucocorticoid system may be hampered by exposure to heavy metals and this system plays important role in carbohydrate, lipid and protein metabolism (Kaltreider et al2001). The significantly $(p<0.01)$ higher values of total cholesterol and triglycerides in heavy metal exposed buffaloes of current study have been observed by other workers Hanan, 2013 and Vaseem, 2013 may be due to disturbance of lipid metabolism and liver dysfunction. The higher values of these metabolites may be due to changes in lipid metabolism leads to impairment of these crucial pathways (Javed et al., 2017).

Increased plasma glucose, total cholesterol, triglycerides with decreased plasma protein and albumin in arsenic and lead exposed cattle and mice have been recorded by El-Nekeety et al., 2009, Rana et al., 2010 and Mohajeri et al., 2014; which is in agreement with the results of the present study. Bar-anowska Bosiacka et al., 2000 reported that metals like lead affect numerous enzymes activities thus inhibiting of enzymes of glycolysis, haem and globin synthesis whichinturn influence the metabolism of erythrocytes this fact is in agreement of the present observations viz; alterations of glucose and total protein in heavy metal exposed buffaloes. High ambient temperature can affect the blood glucose and total cholesterol levels as physiological adaptation mechanisms in dairy animals. The reduced total cholesterol levels during the summer season in both the groups may be due to a reduction in acetate concentration which is the precursor of cholesterol synthesis (Patel et al., 2016). Significantly $(p<0.01)$ decreased total protein in heavy metals exposed buffaloes may be due to

Correlation Coefficient between Heavy Metals and Biochemical Constituents: Heatmap

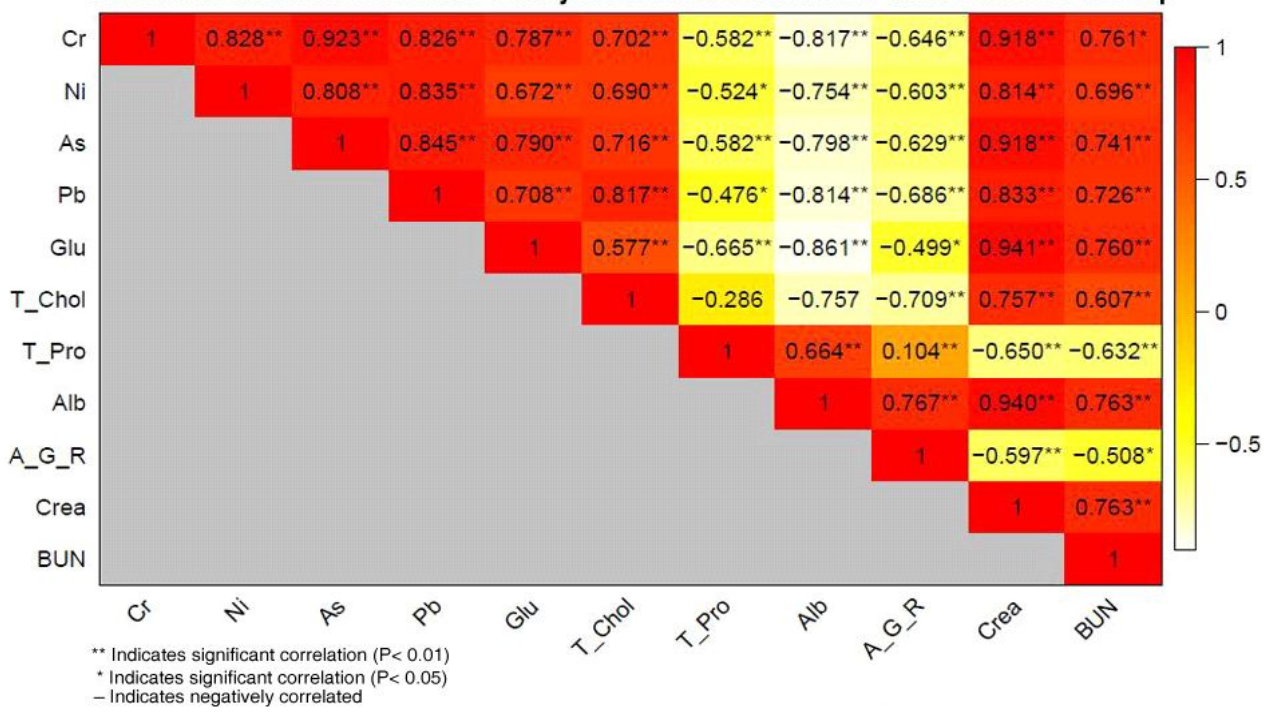

Fig 1: Correlation coefficient between heavy metals and blood biochemical constituents metabolic profile. 
toxic effects of these metals on protein biosynthesis and metal salts reduce the plasma protein content is in agreement with the response observed in fish to heavy metal toxicosis by Panigrahi et al., 2016. The reduced levels of total protein, albumin and globulin during the summer season in both the groups in our findings are in accordance with the findings of Dangi et al., 2012 i.e. a significant decrease in total protein, albumin and globulin levels during heat stress in goats. These reduced levels may be due to the heat shock which increases plasma volume and decreases the protein concentrations of plasma. The reduced levels of albumin in the present experiment may be due to the liver dysfunction because of heavy metal toxicosis as albumin is produced by liver, the same observed by Javed et al., 2017 in fish exposed to heavy metal loaded water.

It means there may be a source of pollution that influences the metabolic pathways extensively. Total cholesterol, total protein and albumin levels were negatively correlated $(p<0.01)$ with all other metabolic profile parameters studied in heavy metal exposed areas. This may be due to the effect of heavy metals on amino acid anabolism. Heavy metal pollution may have interactive effect on gly-colysis, Krebs cycle, nucleic acid metabolism, protein metabolism, pentose phosphate pathway and Fatty acid synthesis, glycogen synthesis (Strydom et al., 2006). The

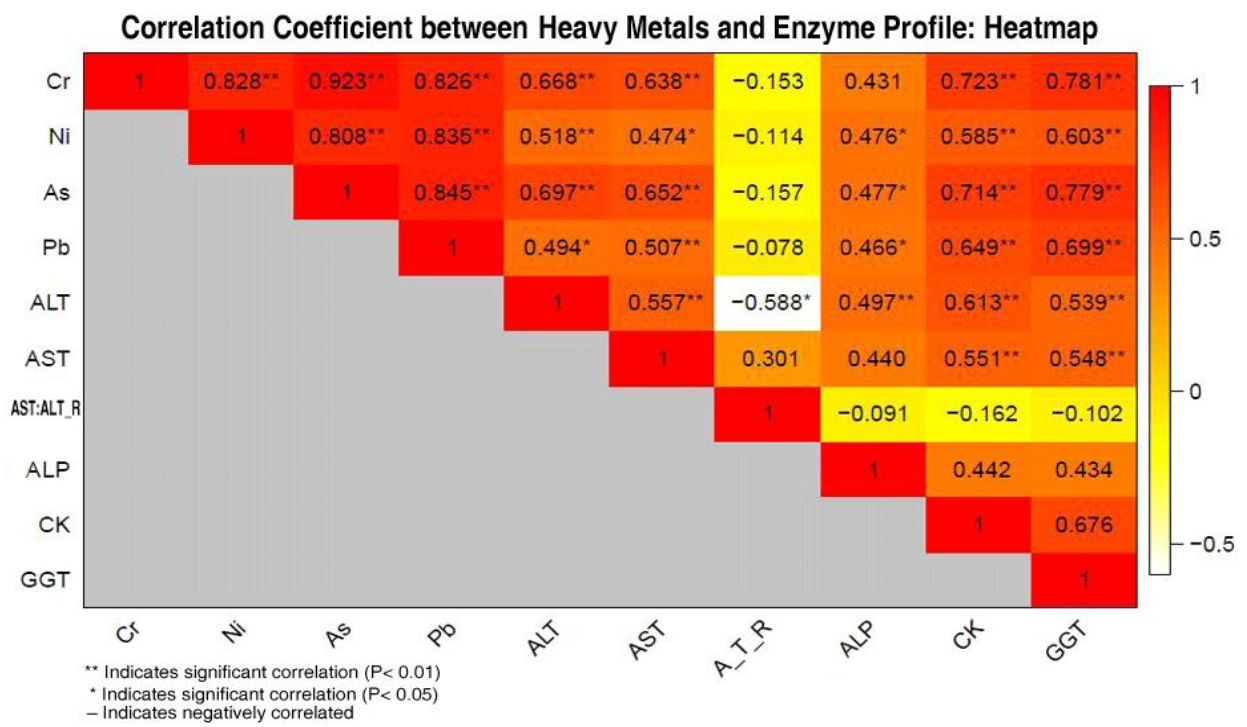

Fig 2: Relationship between heavy metals and enzyme profile in blood of buffaloes of control and exposed areas.

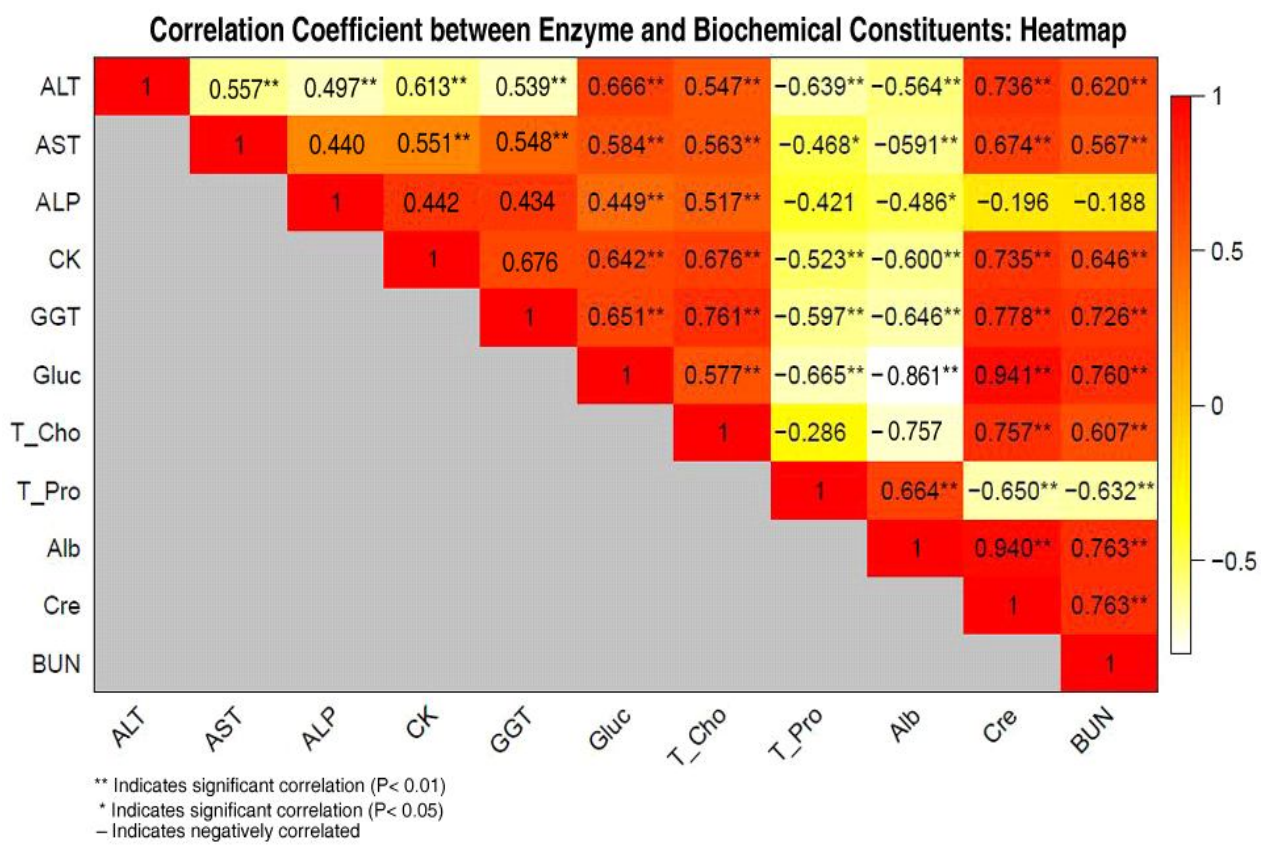

Fig 3: Relationship between enzyme profile and blood biochemical constituents of buffaloes of control and exposed areas. 
elevated levels of creatinine and BUN in heavy metal exposed buffaloes may be possibly due to nephrotoxic metals like $\mathrm{Pb}$ and As (Maxie, 1993). The acute heat stress in young and adult Murrah buffaloes induces the changes in blood metabolites and enzymatic reactions; this may be due to adaptations of the animals to changing climate variables and environmental temperature (Haque et al., 2015, Chaudhary et al., 2015 and Mazuzullo etal., 2014) which support the present results. The elevated levels of creatinine and BUN in heavy metal exposed buffaloes may be due to lead and arsenic which are nephrotoxic metals (Maxie, 1993).

In the present study, significantly higher levels of AST, ALP activities and reduced plasma levels of total protein and albumin clearly suggest the hepatic dysfunction in cattle with higher blood metal levels. Chand et al., (2017) observed the same result in biochemical profile in cattle around industrial effluent contaminated area of kali river of Meerut city. Lead induced hepatic dysfunction in cattle was revealed by the elevated activities of AST, ALP as biomarker for liver functions and synthesis of albumin largely depends on the liver function status (Flora et al., 2012). The significant increase of AST, ALT activity and decreased albumin is in agreement to those results. In hepatocellular liver diseases due to defective albumin synthesis there may be hypoalbuminemia (Chand et al., 2017). Increased ALP and GGT activity observed in the buffaloes naturally exposed to arsenic contamination might be due to hepatic dysfunction (Dash et al., 2016) which is in concurrence with the present study. The elevated activity of GGT is indicative of increased exposure to environmental xenobiotics (Koenig and seneff, 2015). The increased CK activity in cattle with various muscle injuries may be associated with metal toxicity (Kaneko et al., 1997 and Aslani et al. (2012) and Dash et al., 2016). Nickel and lead are cardiotoxic metals (Van Vleet and Ferrans, 1986). Highly significant positive relationship $(P<0.01)$ was observed among the levels of glucose, total cholesterol, triglycerides, creatinine, AST, ALT, ALP, CK and GGT in heavy metal exposed areas. In the present study, all the enzymes analyzed showing seasonal effect during summer. The assessment of enzyme concentrations in plasma or serum interpret the physiological mechanisms as metabolic regulators during stressed conditions and their levels in serum reflects the metabolic activities (Patel et al., 2016). In contrast to our findings, Helal et al., 2010 observed the significantly reduced activity of ALP in heat stressed goats. Results similar to the present study were also observed in goats and found that increased levels of ALT during heat stress whereas, in contrast, no changes observed in AST concentrations in these goats (Sharma et al., 2011). CK activity is higher in the plasma in response to the stress and /muscle damage (Gwaze et al., 2012).

\section{CONCLUSION}

The heavy metal exposed buffaloes during summer season shows the elevated metabolic activities may be due to heavy metal pollution.

\section{ACKNOWLEDGEMENT}

The authors are highly thankful to the Dean, College of Veterinary Science and Director of Research GADVASU, Ludhiana for providing infrastructure and facilities to conduct this study. Authors are also thankfully acknowledge the Director, School of Agricultural Biotechnology, PAU, Ludhiana (Punjab) for allowing the analysis of heavy metals onICP-OES.

\section{Conflict of interest}

The authors declare that they do not have any competing financial interest.

\section{REFERENCES}

Allen, S.E., Grimshaw, H.M. and Rowland, A.P. (1986). Methods in Plant Ecology. Eds., Blackwell Scientific Publication, Oxford, London.

Aslani, M.R., Heidarpour, M., Najarnezhad, V., Mostakavi, M. and Khorasani, Y.T. (2012). Lead poisoning in cattle associated with batteries recycling: High lead levels in milk of nonsymptomatic exposed cattle. Iranian Journal of Veterinary Science and Technology. 4(1): 4752.

Assi, M.A., Hezmee, M.N.M., Haron, A.W., Sabri, M.Y., Rajion, M.A. (2016). The detrimental effects of lead on human and animal health, Veterinary World. 9(6): 660-671.

Bánfalvi, G. (2011). Heavy Metals, Trace Elements and Their Cellular Effects. In: Cellular Effects of Heavy Metals. [Bánfalvi, G., Ed]. New York, Springer, pp 3-28.

Baranowska-bosiacka, Hlynczak, A.J. and Machalin-ski, B. (2000). The impact of lead ions on metabolism of erythro-cytes. Med. Pr. 51(1): 59-65.

Bandopadhyay, D.P. and Das, S.K. (2010). Effect of chronic intake of arsenic-contaminated water on blood oxidative stress indices in cattle in an arsenic-affected zone. Ecotoxicology and Environmental Safety. 73: 1327-1332.

Chand, N., Tyagi, S., Prasad, R., Dutta, D., Sirohi, A.S., Singh, P. and Sharma, A. (2017). Assessment of lead and cadmium status and its effect on biochemical profile of cattle reared around industrial effluent contaminated area. International Journal of Livestock Research. 7(8): 183-188.

Chaudhary, S.S., Singh, V.K., Upadhyay, R.C., Puri, G., Odedara, A.B. and Patel, P.A. (2015). Evaluation of physiological and biochemical responses in different seasons in Surti buffaloes. Veterinary World. 8(7): 727-731.

Chen, Y.W., Yang, C.Y., Huang, C.F., Hung, D.Z., Leung, Y.M., Liu, S.H. (2009). Heavy metals, Islet Function and diabetes development. Islets. 1(3): 169-176. 76.

Christiana, M.A.O. and Samuel, K. (2013). Investigation of heavy metal levels in roadside agricultural soil and plant samples in Adogo, Nigeria. Acad. J. Environ. Sci. 1: 31-35.

Chopra, A.K., Pathak, C. and Prasad, G. (2009). Scenario of heavy metalcontamination in agricultural soil and its management. Journal of Applied and Natural Science. 1: 99-108.

Dangi, S.S., Gupta, M., Maurya, D., Yadav, V.P., Panda, R.P., Singh, G., Mohan, N.H., Bhure, S.K., Das, B.C., Bag, S., Mahapatra, R.K. and Sarkar, M. (2012). Expression Profile of HSP genes during different seasons in goats (Capra hircus). Tropical Animal Health and Productio. 44: 1905-1912. 
Dartsch, P.C., Hildenbr, S., Kimmel, R. and Schmahl, F.W. (1998). Investigations on the Phrotoxicityand hepatotoxicity of trivalent andhexavalent chromium compounds. International Archives and Occupational Environmental Health. 71 suppl: S40-5.

Dash, S.K., Nayyar, S., Jindal, R. and Mukhopadhyay, C.S. (2016). Plasma enzyme Activities in buffaloes (Bubalus bubalis) naturally exposed to arsenic contamination. Indian Veterinary Journal. 93(10): 42- 44.

Dhanalakshmi, B. and Gawdaman, G. (2013). Determination of heavy metals in goat milk Through icp-oes, Asian Journal of Dairy and Food Research. 32(3): 186-190.

El-Nekeety, A.A., El-Kady, A.A., Soliman, M.S., Hassan, N.S. and Abdei-Wahhab, M.A. (2009). Protective effect of Aqualegia vulgaris (L.) against lead acetate-Induced oxidative stress in rats. Food and Chemical Toxicology. 47: 2209-15.

Flora, G., Gupta, D., Tiwari, A. (2012). Toxicity of lead: A review with recent updates. Interdisciplinary Toxicology. 5(2): 47-58.

FSSAI. (2010). Food Safety and Standards Act of India. Food Safety and Standards Regulations. pp. 442-529.

Gwaze, F.R., Chimonyo, M., Dzama, K. (2012). Effect of season and age on blood minerals, liver enzyme levels and faecal egg counts in Nguni goats of South Africa. Czech Journal of Animal Science. 57(10): 443-453.

Haque, N., Ludri, A.., Hossain, S.A. and Ashutosh, M. (2015). Alteration of metabolic profiles in young and adult Murrah buffaloes exposed to acute heat stress. International Journal of Applied Animal Science. 1(1): 23-29.

Hajeb, P., Sloth, J.J., Shakibazadeh, S., Mahyudin, N.A. and AfsahHejri, L. (2014). Toxic elements in food: Occurrence, binding and reduction approaches. Comprehensive Reviews in Food Science and Food Safety. 13: 457-72.

Helal, A., Hashem, A.L.S., Abdel-Fattah, M.S. and El-Shaer. (2010). Effects of heat stress on coat characteristics and physiological responses of balady and Damascus goat in Sinai Egypt. American Euresian Journal of Agriculture and Environmental Science. 7(1): 60-69.

Jacob, S.E., Goldenberg, A., Pelletier, J.L., Fonacier, L.S., Usatine, R., Silverberg, N. (2015). Nickel allergy and our children's health: A review ofindexed cases and a view of future prevention. Pediatrics Dermatology. 32: 779-85.

Javed, M., Ahmad, M.I., Usmani, N. and Ahmad, M. (2017). Multiple biomarker responses (Serum biochemistry, oxidative stress, genotoxicity and histopathology) in annapunctatus exposed to heavy metal loaded waste water. Science Reports. 7: 1675-1693.

Kaltreider, R.C., Davis, A.M., Lriviere, J.P. and Hamilton, J W. (2001). Arsenic alters the function of the glucocorticoid receptor as a transcription factor. Environmental Health Perspectives. 109: 245-51.

Kaneko, J.J., Harvey, J.W. and Bruss, M.L. (1997). Clinical Biochemistry of Domestic Animals. $6^{\text {th }}$ edn. Elsevier Inc., Oxford, United Kingdom.

Kazi, T.G., Jalbani, N., Kazi, N., Arain, M.B., Jamali, M.K., Afridi, H.I., Kandhro, G.A., Sarfraz, R.A., Shah, A.Q., Ansari, R. (2009). Estimation of toxic metals in scalp hair samples of Chronic kidney patients. Biological Trace Elements Research. 127(1): 16-27.
Koenig, G. and Seneff, S. (2015). Gamma-Glutamyl transferase: A Predictive Biomarker of Cellular Antioxidant Inadequacy and Disease risk. Disease Markers. 1-18.

Lakhani., Jindal, R. and Nayyar, S. (2016). Effect of Heat Stress on Humoral Immunity and its Amelioration by Amla Powder (Emblicaofficinalis) Supplementation in Buffaloes. Journal of Animal Research. 6 (3): 401-404.

Lavicoli, I., Fontana, L. and Bergamaschi, A. (2009). The effects of metals as endocrine Disruptors. Journal of Toxicology and Environmental Health Part B. 12(3): 206-223.

Maxie, M.G. (1993). The Urinary System. Pathology of Domestic Animals, eds. [Jubb, K.V.F., Kennedy, P.C., Palmer, N., $4^{\text {th }}$ ed.], Academic Press, San Diego, CA. vol. 2, pp. 488-500.

Mazzullo, G., Rifici, C., Lombardo, S.F., Agricola, S., Rizzo1, M., Piccione, G. (2014). Seasonal variations of some blood parameters in cows. Large Animal Review. 20: 81-84.

McGrath, S.P. and Cunliffe, C.H. (1995). A simplified method for the extraction of the metals in sewage sludge on soils, microorganisms and plants. Journal of Industrial Microbiology. 14: 94-104.

Mohajeri, G., Norouzian, M.A., Mohseni, M. and Afzalzadeh, A. (2014). Changes in blood metals, hematology and hepatic enzyme activities in lactating cows reared in the vicinity of a lead zinc smelter. Bulletin of Environmental Contamination and Toxicology. 92: 693-97.

Ozan, T.S. (2015). Levels of some heavy metals in water and sediment compared with season and some physic-chemical parameters from antyala bay. Indian Journal of Geo-Marinescience. 44(9): 1393-1400.

Panigrahi, A., Dasmahapatra, A. and Medda, A.K. (2016). Responsiveness of Total Plasma Protein After Administration of Some Toxic Heavy Metals in an Indian Teleost (Clariasbatrachus L.). American Journal of Bio Science. 4(5): 64-73.

Patel, M.D., Patel, J.H., Rajput, M.B. and Bariy, A.R. (2016). Adaptive physiological and biochemical responses of dairy animals to heat stress: A review; International Academy of Science, Engineering and Technology. 5(1): 107-116.

Patlolla, A.K., Todorov, T.I., Tchounwou, P.B., van der, Voet, G., Centeno, J.A. (2012). Arsenic-Induced biochemical and genotoxic effects and distribution in tissues of Sprague-Dawley rats.

Rana, T., Bera, A.K., Das, S. (2010). Bhattacharya Microchemical Journal. 105: 101-7.D,

Sharma, A.K. and Kataria, N. (2011). Effects of extreme hot climate on liver and serum enzymes in Marwari goat. Indian Journal of Animal Science. 81(3): 293-295.

Strydom, C., Robinson, C., Pretorius, E., Whitcutt, J.M., Marx, J. and Bornman, M.S. (2006). The effect of selected metals on the central metabolic pathways in biology: $\mathrm{A}$ review, = Water SA. 32(4): 543-554.

Van Vleet, J.F. and Ferrans, V.J. (1986). Myocardial disease of animals. The American Journal of Pathology. 124: 98-174.

Vimercati, L., Gatti, M.F., Gagliardi, T., Cuccaro, F., Maria, L.D., Caputi, A., Quarato, M. and Baldassarre, A. (2017). Environmental exposure to arsenic and chromium in an Industrial area. Environmental Science Pollution Research. 24: 11528-11535.

Yeotikar, P.V., Nayyar, S., Singh, C., Mukhopadhaya, C.S., Kakkar, S.S. and Jindal, R. (2018). Levels of heavy metals in drinking water, blood and milk of buffaloes during summer and winter seasons in Ludhiana, Punjab (India), International Journal of Pure and Applied Biosciences. 6(2): 1265-1274. 